\title{
Editorial
}

\section{Muscarinic receptor subtypes: implications for lung disease}

\section{Introduction}

Dale in 1914 first showed that acetylcholine produced two types of response, which were mimicked by nicotine and by muscarine, and that the muscarinic action was blocked by atropine.' Only very recently, however, have muscarinic receptors been subdivided. This has been made possible by the development of selective drugs, and muscarinic receptor subtypes have now been identified in several tissues. ${ }^{23}$ The evidence for muscarinic receptor subtypes was initially challenged, but advances in molecular biology have confirmed their existence and as many as five different receptor subtypes have now been cloned and expressed. ${ }^{47}$ The precise relation between these cloned receptor subtypes and receptors identified pharmacologically, however, is still not clear and the drugs that differentiate receptor subtypes lack a high degree of selectivity.

\section{Muscarinic receptor classification}

There is still some confusion over the classification and nomenclature of muscarinic receptors. At least three distinct receptor subtypes have been differentiated pharmacologically, both by radioligand binding assays and by functional studies. ${ }^{8}$

Pirenzepine was the first selective muscarinic antagonist to be recognised, ${ }^{9}$ and pirenzepine sensitive muscarinic receptors are termed $\mathbf{M}_{1}$ receptors. Other muscarinic receptors were termed $\mathbf{M}_{2}$ receptors, until it became clear that they were heterogeneous as new antagonists, such as AF-DX $116^{10}$ and methoctramine, ${ }^{11}{ }^{12}$ were developed. $\mathbf{M}_{2}$ receptors in atria were clearly different from those in smooth muscle and glands, which have now been termed $\mathbf{M}_{3}$ receptors. $\mathbf{M}_{3}$ receptors are selectively blocked by 4-diphenylacetoxy- $N$-methyl piperidine methiodide (4-DAMP) and hexahydrosiladifenidine. Further subdivision may be possible with the development of more selective drugs. The recognition of muscarinic

Address for reprint requests: Professor P J Barnes, Department of Thoracic Medicine, National Heart and Lung Institute, London SW3 6LY. subtypes is more than a pharmacological curiosity as it is now clear that the subtypes may have different physiological roles, may be coupled to different transduction mechanisms, and may be differentially regulated.

Recent research has shown that different subtypes of muscarinic receptor are present in the airways of several species, including $\operatorname{man}^{13-15}$ (fig 1). These observations may have clinical importance, as the receptor subtypes will have different functions and the development of selective drugs may therefore be of clinical benefit in the treatment of airway disease.

\section{Muscarinic receptors in airways}

Cholinergic nerves are the predominant neural pathway in human airways ${ }^{1617}$ and cholinergic bronchoconstriction may be important in airway obstruction. Cholinergic nerves pass down the vagus nerve to form synapses in parasympathetic ganglia within the airway wall, from which short postganglionic fibres pass to target cells, which include airway smooth muscle and submucosal glands. Acetylcholine is released from postganglionic nerve varicosities, leading to contraction of airway smooth muscle and mucus secretion, effects that are blocked by muscarinic antagonists such as atropine or ipratropium bromide. Autoradiographic mapping studies have shown that muscarinic receptors are localised to airway smooth muscle cells and to submucosal glands in the airways of animals ${ }^{18}$ and man. ${ }^{19}$ Muscarinic receptors are also localised to nerves and parasympathetic ganglia but they are not found on epithelium or bronchial vessels.

\section{$M_{1}$ RECEPTORS}

$M_{1}$ receptors with a high affinity for pirenzepine are generally found in the cerebral cortex and on autonomic ganglia. ${ }^{20}$ Pirenzepine is used clinically to reduce gastric acid secretion and, although it was previously believed to act directly on acid secreting cells, it is now apparent that it acts predominantly on ganglia in the stomach to inhibit neurally mediated gastric secretion. ${ }^{21}$ As the innervation of the airways is derived embryologically from that of the gut, 


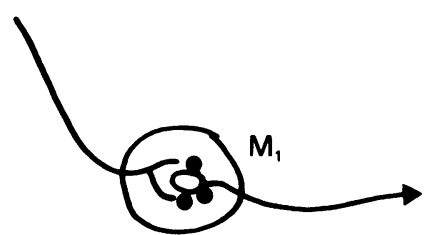

Ganglion

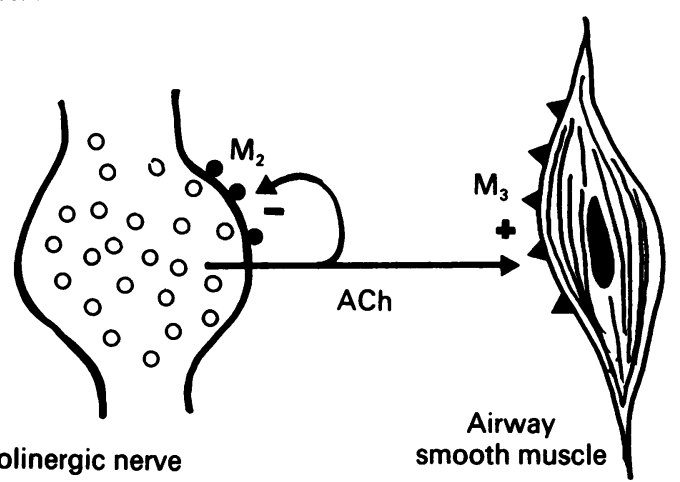

$\mathrm{M}_{2}$

Pilocarpine
AGONIST MCN-A-343

ANTAGONIST Pirenzepine
Gallamine

AF-DX 116

Methoctramine
$M_{3}$

4-DAMP

Hexahydrosila-difenidol

Fig 1 Muscarinic receptor subtypes in airways. $M_{1}$ receptors are localised to parasympathetic ganglia, facilitating neurotransmission; $M_{2}$ receptors to cholinergic nerves, inhibiting acetylcholine $(A C h)$ release (autoreceptors); and $M_{3}$ receptors to airway smooth muscle. From Barnes et al ${ }^{13}$; reproduced by courtesy of "Trends in Pharmacological Science."

excitatory $M_{1}$ receptors seem likely to exist also in airway ganglia. There appear to be considerable species differences in the location of muscarinic receptors in pulmonary nerves, however. Pirenzepine was shown to be very effective in blocking bronchoconstriction due to stimulation of the vagus nerve in both rabbits ${ }^{22}$ and dogs, ${ }^{23}$ although the studies did not clearly show that pirenzepine was effective at doses that had little action on the direct bronchoconstrictor action of acetylcholine. In vitro, pirenzepine has a low potency against acetylcholine induced contraction of rabbit airways ${ }^{22}$ and for binding of the non-selective antagonist $\left[{ }^{3} \mathrm{H}\right] q$ quinuclidinyl benzilate to bovine airways, ${ }^{24}$ suggesting that $M_{1}$ receptors are not present in airway smooth muscle. Similarly, pirenzepine is only weakly effective in inhibiting the phosphoinositide turnover stimulated by cholinergic agonist in bovine airway smooth muscle. ${ }^{24}$

Pirenzepine is a bronchodilator when given intravenously to human subjects, ${ }^{2627}$ although at the dose used it might be acting non-selectively and blocking smooth muscle muscarinic receptors. A recent study has shown that lower doses of intravenous pirenzepine, although having no effect on $\mathrm{FEV}_{1}$, increase expiratory flow at low lung volumes, indicating perhaps a selective action on peripheral airways. $^{28}$
Recent evidence suggests that $M_{1}$ receptors may als $\overline{\vec{Q}}$ be present on human airway cholinergic nerves. The effects of inhaled pirenzepine and ipratropiun bromide on cholinergic reflex bronchoconstriction. triggered by inhalation of sulphur dioxide, were compared in atopic subjects. A dose of inhale pirenzepine was found that failed to inhibi significantly the bronchoconstriction due to inhaled. methacholine (which acts directly on airway smooth. muscle), whereas ipratropium bromide was able to block this response as expected. The same dose of pirenzepine, however, was as effective as ipratropium bromide in blocking bronchoconstriction induced b sulphur dioxide, and as it could not be acting directly. on airway smooth muscle receptors it must be acting on some part of the cholinergic reflex pathway. ${ }^{29}$ This is most likely to be the parasympathetic ganglia in the airways, which may be accessible to inhaleg pirenzepine. In support of this possibility, pirenzepine has been shown to depress parasympathetic neur\& transmission in rabbit bronchi in vitro. ${ }^{30}$ Furthermore human airway parasympathetic ganglia show a high density of muscarinic receptors in autoradiographig studies. ${ }^{19}$

The physiological role of $\mathbf{M}_{1}$ receptors in autonomi ganglia is still not certain. Classically, ganglionie transmission is via nicotinic cholinergic receptors 
which are activated by nicotine and blocked by hexamethonium. Possibly excitatory $\mathbf{M}_{1}$ receptors are facilitatory to nicotinic receptors and may play a part in "setting" the efficacy of ganglion transmission. Activation of these receptors probably closes potassium channels, resulting in a slow depolarisation of the ganglion cell..$^{31}$ They might perhaps have a role in the long term regulation of cholinergic tone, whereas nicotinic receptors are more important in rapid signalling, such as occurs during reflex activation of the cholinergic pathway. If so, $\mathbf{M}_{1}$ antagonists such as pirenzepine or telenzepine might have a useful therapeutic role in asthma as they may reduce vagal tone. As increased vagal tone may have an important role in nocturnal exacerbations of asthma, ${ }^{3233}$ pirenzepine might prove to be efficacious in preventing nocturnal wheeze.

$M_{1}$ receptors have also been detected in the lungs by radioligand binding studies, but the results are unexpected. Binding of $\left[{ }^{3} \mathrm{H}\right]$ quinuclidinyl benzilate to both rabbit and human peripheral lung membranes is displaced by pirenzepine with a shallow inhibitory curve, suggesting the presence of high and low affinity sites. $^{34-36}$ The high affinity binding site has the characteristics of an $\mathbf{M}_{1}$ receptor; the use of $\left[{ }^{3} \mathrm{H}\right]$ pirenzepine, which selectively labels this receptor subtype, has provided confirmation. $\mathbf{M}_{1}$ receptors make up more than half of the binding sites in the human lung. This cannot possibly be accounted for by receptors on parasympathetic ganglia or nerves, which would make up only a small fraction of the membranes. Recent autoradiographic mapping of muscarinic receptor subtypes in human airways has shown that $M_{1}$ receptors are present on submucosal glands and not on airway smooth muscle. They are also found on alveolar walls, which would account for the high density of $M_{1}$ receptors in peripheral lung. ${ }^{37}$ The function of $M_{1}$ receptors in alveoli is not known.

\section{$M_{2}$ RECEPTORS}

Muscarinic receptors in the atria, which mediate tachycardia, are of the $\mathbf{M}_{2}$ subtype and are selectively blocked by gallamine, AF-DX 116, and methoctramine.$^{10-12}$ Methoctramine is the most selective of the muscarinic antagonists currently available and it clearly distinguishes $\mathbf{M}_{\mathbf{2}}$ ("atrial type") receptors from those in smooth muscle. ${ }^{12} \mathrm{M}_{2}$ receptors are selectively activated by pilocarpine and blocked by gallamine.

$M_{2}$ receptors have now been described in airways; they are localised to the cholinergic nerves themselves and function as feedback inhibitory receptors or autoreceptors. Muscarinic receptors that inhibit the release of acetylcholine from cholinergic nerves are well recognised in the gut, ${ }^{38}$ so it is not surprising to find similar receptors in airway cholinergic nerves. These autoreceptors are inhibited by gallamine and are therefore classified as $\mathbf{M}_{\mathbf{2}}$ receptors, thus differing from the muscarinic receptor subtypes on airway smooth muscle, which are classified as $\mathbf{M}_{3}$ receptors. ${ }^{39}{ }^{40} \mathrm{M}_{2}$ receptors appear to be located before the junctions on postganglionic parasympathetic nerves, ${ }^{41}$ where they have a powerful inhibitory effect on acetylcholine release. Muscarinic autoreceptors have now been identified in guinea pig, ${ }^{39}{ }^{42}$ cat, ${ }^{40}$ and dog airways, ${ }^{43}$ but they are lacking in the rat and rabbit. ${ }^{39}$ Recently, similar feedback inhibitory receptors have been localised to postganglionic cholinergic nerves in human airways in vitro. ${ }^{42}$

Pilocarpine, a selective agonist of $\mathbf{M}_{2}$ receptors, inhibits cholinergic nerve induced contraction of human bronchi elicited by electrical field stimulation, while not affecting contraction induced directly by acetylcholine. This suppressive effect is blocked in a non-competitive manner by gallamine, confirming that it is mediated by an $\mathbf{M}_{2}$ receptor, which is presumably localised to postganglionic cholinergic nerves. ${ }^{42}$ The suppressive effect of these autoreceptors is substantial, with complete inhibition of cholinergic nerve activity with higher doses of pilocarpine. Autoradiographic studies have shown muscarinic receptors on human airway cholinergic nerves. ${ }^{1937}$ In binding studies of human lung homogenates no appreciable population of $\mathbf{M}_{2}$ receptors has been identified ${ }^{36}$ although cholinergic nerves must make up only a trivial proportion of lung membranes and so their contribution to a lung homogenate would not be likely to be detected.

In normal subjects pilocarpine, which selectively stimulates prejunctional receptors (but has some direct effect on airway smooth muscle receptors and so causes bronchoconstriction), had an inhibitory effect on cholinergic reflex bronchoconstriction induced by sulphur dioxide, whereas a similar degree of bronchoconstriction with histamine did not affect the bronchoconstriction induced by sulphur dioxide. ${ }^{44}$ This suggests that these inhibitory receptors may be present in vivo, presumably serving to limit cholinergic bronchoconstriction. In asthmatic patients pilocarpine had no such inhibitory action, indicating that there might be some dysfunction of the autoreceptor; this might result in exaggerated cholinergic reflex bronchoconstriction. ${ }^{44}$ The reason why muscarinic autoreceptors may be dysfunctional in asthma is not certain. Possibly inflammatory changes in the airways lead to a reduction in muscarinic receptor number or coupling. This would have little or no effect on airway smooth muscle muscarinic receptors, which are very much in excess, but there may not be as many "spare" prejunctional receptors and they would therefore be more susceptible to damage. 


\section{$M_{3}$ RECEPTORS}

The muscarinic receptors on airway smooth muscle are sensitive to 4-DAMP and hexahydrosiladifenidol and are therefore classified as $\mathbf{M}_{3}$ receptors. Binding studies in guinea pig lung membranes indicate a preponderance of $\mathbf{M}_{3}$ receptors, whereas in human lung $\mathbf{M}_{3}$ receptors make up less than half of the receptors (the remainder being $\left.\mathbf{M}_{1}\right){ }^{36}$ Autoradiographic mapping studies have shown that $\mathbf{M}_{3}$ receptors are localised to airway smooth muscle and to submucosal glands. ${ }^{37}$ Muscarinic receptors in airway smooth muscle are linked to phosphoinositide breakdown ${ }^{24}$ and the formation of inositol-1,4,5-triphosphate ${ }^{45}$ which releases calcium ions from intracellular stores.

Autoradiographic studies suggest that submucosal glands have both $M_{1}$ and $M_{3}$ receptors, which are both presumed to stimulate mucus secretion. Functional studies with selective antagonists in isolated cat trachea suggest a response intermediate between $M_{1}$ and $M_{3}$ receptors, supporting the view that both receptor subtypes may play a part in airway mucus secretion. ${ }^{46}$

\section{Clinical relevance}

The discovery of at least three muscarinic subtypes in the lung has important clinical implications, as it raises the possibility of more selective anticholinergic treatment in the future. Atropine, ipratropium bromide, and oxitropium bromide are non-selective anticholinergic drugs blocking prejunctional $\left(\mathbf{M}_{2}\right)$ and postjunctional $\left(\mathrm{M}_{3}\right)$ receptors with equal affinity. Inhibition of the autoreceptor means that more acetylcholine will be released during cholinergic nerve stimulation and this may overcome postjunctional blockade, thus making these non-selective antagonists less efficient than a selective antagonist of $\mathbf{M}_{2}$ receptors. Alpha adrenoreceptors are analogous; the nonselective antagonist phentolamine, by acting on a prejunctional alpha ${ }_{2}$ receptor, increases noradrenaline release and is thus far less effective in the treatment of hypertension than a selective alpha $a_{1}$ antagonist such as prazosin, which acts only on the postjunctional receptor. Unfortunately, muscarinic drugs with the high selectivity of prazosin for postjunctional receptors are not yet available.

Blockade of muscarinic autoreceptors by anticholinergic drugs might account for paradoxical bronchoconstriction after a metered dose aerosol of ipratropium bromide in patients with chronic obstructive airways disease. ${ }^{47}$ In guinea pigs ipratropium bromide in low doses potentiates vagally induced bronchoconstriction, ${ }^{48}$ lending support to the idea that non-selective muscarinic antagonists might exacerbate bronchoconstriction by an action on prejunctional $\mathbf{M}_{2}$ receptors. Such problems would not be expected from: $M_{3}$ selective antagonists.

\section{Beta blocker induced asthma}

The worsening of asthma by beta blocking drugs remains a problem and deaths continue to be reported Even beta blocker eye drops are capable of precipitat=ing an asthma attack. ${ }^{49}$ The cause has remained elusive, although cholinergic mechanisms may have critical role as anticholinergic drugs may completelye prevent the bronchoconstriction due to inhaled pro $\overline{\vec{x}}$ pranolol. ${ }^{50}$ Muscarinic autoreceptors might help top explain how catastrophic bronchoconstriction may be precipitated by even a small dose of a beta blocking. drug. Beta blocking drugs inhibit adrenergic bronchodilator tone, which in man is probablye provided by circulating adrenaline. ${ }^{51}$ Beta $_{2}$ receptors that when activated inhibit the release of acetylcholine have now been found on cholinergic nerves of humar bronchi, ${ }^{52}$ and when these are blocked an increase in $\mathrm{P}$ tonic acetylcholine release would be expected. In $\overrightarrow{0}$ normal individuals the acetylcholine would activate these autoreceptors to shut off any further acetyl choline release and thus no bronchoconstriction would occur. In asthmatic patients the same increase in acetylcholine would occur but, because of the apparent defect in muscarinic autoreceptors, ${ }^{44}$ thereD would be no mechanism for switching off acetyl choline release. Furthermore, the asthmatic airway is hyperresponsive to acetylcholine, and thus even low doses of a beta blocker may precipitate a catastrophic bronchoconstrictor response (fig 2).

\section{Summary and conclusions}

Several subtypes of muscarinic receptor have now been identified and have been found recently in the airways of several species, including man, a discovery that may have important clinical implications. $\mathbf{M}_{\mathbf{O}}$ receptors may be found in parasympathetic ganglia $M_{2}$ receptors on cholinergic nerves (autoreceptors) and $M_{3}$ receptors on airway smooth muscle and mucus secreting glands. It is suggested that a defect in $\mathbf{M}$ receptor function may help to explain why asthman may be induced by beta blocking drugs. Furtheñ elucidation of the physiological role for these recepto 5 subtypes will probably depend on the development of more selective antagonists. Drugs such as methoce tramine, which have a high degree of selectivity for $\mathbf{M}_{5}$ receptors, are promising tools for elucidating the role of muscarinic receptor subtypes," but drugs with क5 higher selectivity for $M_{1}$ and $M_{3}$ receptors are likelyo to be most useful clinically in airway disease; in particular, $\mathbf{M}_{3}$ blockers will not be associated with increased acetylcholine release. The recent availability 


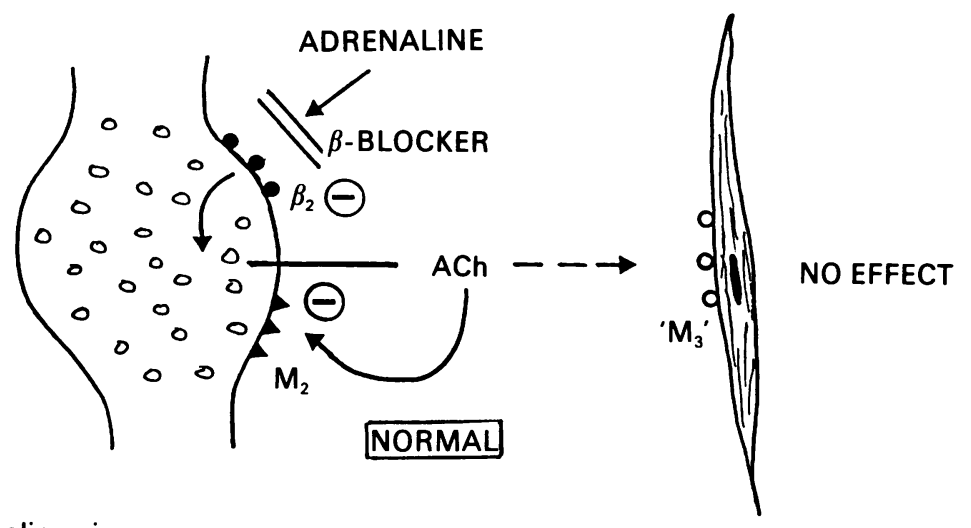

Cholinergic nerve

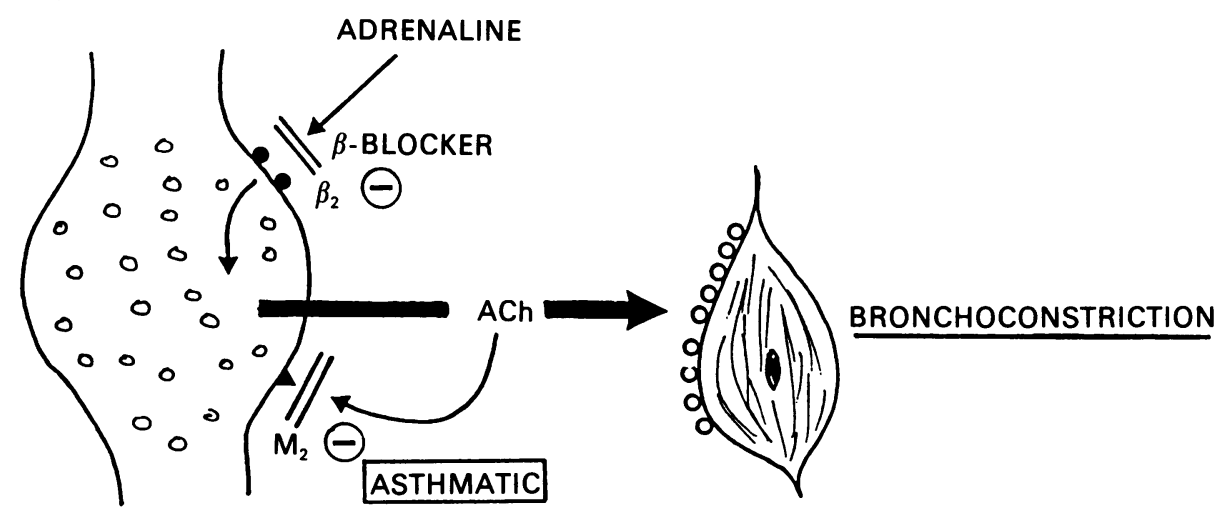

Fig 2 Possible mechanisms of beta blocker induced asthma implicating a dysfunction of muscarinic autoreceptors. Beta blockers inhibit the tonic inhibitory action of adrenaline on cholinergic nerve beta receptors and lead to increased acetylcholine $(A C h)$ release. In normal individuals this is switched off by activation of $M_{2}$ autoreceptors. In asthmatic patients these receptors may be dysfunctional, so more acetylcholine is released. In addition, airway smooth muscle is hyperresponsive to acetylcholine in asthma, so substantial bronchoconstriction may ensue.

of cloned muscarinic receptor subtypes, and the application of in situ hybridisation techniques, should also point the way to studying differential regulation of muscarinic receptor expression in disease.

I thank Madeleine Wray for her careful preparation of this manuscript.

\section{P J BARNES \\ Department of Thoracic Medicine National Heart and Lung Institute London SW3 $6 L Y$}

\section{References}

1 Dale HH. The action of certain esters and ethers of choline, and their relation to muscarine. J Pharmacol Exp Ther 1914;6:147-90.

2 Eglen RM, Whiting RL. Muscarinic receptor subtypes: a critique of the current classification and a proposal for a working nomenclature. J Auton Pharmacol 1986; 5:323-46.

3 Mitchelson F. Muscarinic receptor differentiation. Phar- macol Ther 1988;37:357-423.

4 Kubo T, Fukuda K, Mikami A, et al. Cloning, sequencing and expression of complimentary DNA encoding the muscarinic acetylcholine receptor. Nature 1986; 323:411-6.

5 Bonner TI, Buckley NJ, Young AC, Brann MR. Identification of a family of muscarinic acetylcholine receptor genes. Science 1987;237:527-32.

6 Peralta EG, Winslow JW, Peterson GL, et al. Primary structure and biochemical properties of an $M_{2}$ muscarinic receptor. Science 1987;236:600-5.

7 Bonner TI, Young AC, Brann MR, Buckley NJ. Cloning and expression of the human and rat $\mathbf{M}_{5}$-muscarinic acetylcholine receptor genes. Neuron 1988;1:403-10.

8 Doods HN, Mathay M-J, Davidesko D, van Charldorp $\mathrm{KJ}$, de Jonge A, van Zwieten PA. Selectivity of muscarinic antagonists in radioligand and in vivo experiments for the putative $\mathrm{M} 1, \mathrm{M} 2$ and $\mathrm{M} 3$ receptors. J Pharmacol Exp Ther 1987;242:257-62.

9 Hammer R, Berrie CP, Birdsall NJM, Burgen AS, Hulme EC. Pirenzepine distinguishes between different subclasses of muscarinic receptors. Nature 1980;283:90-2.

10 Hammer R, Giraldo GB, Schiavi E, Monterini E, 
Ladinsky $\mathbf{H}$. Binding profile of a novel cardioselective muscarinic receptor antagonist, AF-DX 116, to membrane of peripheral tissues and brain in the rat. Life Sci 1986;38:1653-8.

11 Melchiorre C. Polymethylene tetramines: a new generation of selective muscarinic antagonists. Trends Pharmacol Sci 1988;9:216-20.

12 Michel AD, Whiting RL. Methoctramine, a polymethylene tetramine, differentiates three subtypes of muscarinic receptor in direct binding studies. Eur $J$ Pharmacol 1988;145:61-6.

13 Barnes PJ, Minette PA, Maclagan J. Muscarinic receptor subtypes in lung. Trends Pharmacol Sci 1988;9:412-6.

14 Gross NJ, Barnes PJ. A short tour round the muscarinic receptor. Am Rev Respir Dis 1988;138:765-7.

15 Minette PA, Barnes PJ. Muscarinic receptor subtypes in airways: function and clinical significance. $A m \operatorname{Rev}$ Respir Dis (in press).

16 Barnes PJ. Neural control of human airways in health and disease. Am Rev Respir Dis 1986;134:1289-314.

17 Barnes PJ. Cholinergic control of airway smooth muscle. Am Rev Respir Dis 1987;136:42-5.

18 Barnes PJ, Nadel JA, Roberts JM, Basbaum CB. Muscarinic receptors in lung and trachea: autoradiographic localization using $\left[{ }^{3} \mathrm{H}\right]$ quinuclidinyl benzilate. Eur $J$ Pharmacol 1982;86:103-6.

19 van Koppen CJ, Blankesteijn WM, Klaasen ABM, et al. Autoradiographic visualization of muscarinic receptors in human bronchi. J Pharmacol Exp Ther 1987; 224:760-4.

20 Hammer P, Giachetti A. Muscarinic receptor subtypes: $\mathbf{M}_{1}$ and $\mathbf{M}_{2}$ biochemical and functional characterization. Life Sci 1982;31:2991-8.

21 Hirschowitz BI, Fong J, Molina E. Effects of pirenzepine and atropine on vagal and cholinergic gastric secretion and gastric release and on heart rate in the dog. $J$ Pharmacol Exp Ther 1983;225:263-8.

22 Bloom JW, Yamamura HI, Baumgartner C, Halonen M. A muscarinic receptor with high affinity for pirenzepine mediates vagally induced bronchoconstriction. Eur $J$ Pharmacol 1987;133:21-7.

23 Beck KC, Vettermann J, Flavahan NA, Rehder K. Muscarinic $M_{1}$ receptors mediate the increase in pulmonary resistance during vagus nerve stimulation in dogs. Am Rev Respir Dis 1987;137:1135-9.

24 Grandordy BM, Cuss FM, Sampson AS, Palmer JB, Barnes PJ. Phosphatidylinositol response to cholinergic agonists in airway smooth muscle: relationship to contraction and muscarinic receptor occupancy. $J$ Pharmacol Exp Ther 1986;238:273-9.

25 Madison JM, Jones CA, Tom-Moy M, Brown JR. Affinities of pirenzepine form muscarinic cholinergic receptors in membranes isolated from bovine tracheal mucosa and smooth muscle. Am Rev Respir Dis 1987;135:719-24.

26 Sertl K, Meryn S, Graninger W, Lagnner A, Schlick W, Ramers H. Acute effects of pirenzepine on bronchospasm. Int J Clin Pharmacol Ther Toxicol 1986;24: 655-7.

27 Morrison JFJ, Pearson SB. Type 1 muscarinic receptors in asthma [abstract]. Am Rev Respir Dis 1988; 137:A197.
28 Cazzola M, Rano S, de Santis D, Principe PJH, Marmo E. Respiratory responses to pirenzepine in healthy subjects. Int J Clin Pharmacol Ther Toxicol 1987; 25:105-9.

29 Lammers J-W, Minette P, McCusker M, Barnes PJ. The role of pirenzepine-sensitive $\left(M_{1}\right)$ muscarinic receptors $\stackrel{\bar{T}}{\supset}$ in vagally mediated bronchoconstriction in humans. Am Rev Respir Dis 1989 (in press).

30 Bloom JW, Baumgartner-Folkerts C, Palmer JD, Yamamura HI, Halonen M. A muscarinic receptor? subtype modulates vagally stimulated bronchial con- $\overrightarrow{-}$ traction. J Appl Physiol 1988;85:2144-50.

31 Ashe JH, Yarosh CA. Differential and selective antagonism of the slow-inhibitory postsynaptic potential and $\vec{x}$ slow-excitatory postsynaptic potential by gallamine and pirenzepine in the superior cervical ganglion of thei rabbit. Neuropharmacology 1984;23:1321-9.

32 Coe CI, Barnes PJ. Reduction of nocturnal asthma by an inhaled anticholinergic drug. Chest 1986;90:485-8.

33 Morrison JFJ, Pearson SB, Dean HG. Parasympathetic nervous system in nocturnal asthma. $\mathrm{Br} \mathrm{Med} J_{3}$ 1988;296:1427-9.

34 Bloom JW, Halonen M, Lawrence LJ, Rould E, Seaver NA, Yamamura HI. Characterization of high affinity $\left[{ }^{3} \mathrm{H}\right]$ pirenzepine and $(-)-\left[{ }^{3} \mathrm{H}\right]$ quinuclidinyl benzilateo binding to muscarinic cholinergic receptors in rabbite peripheral lung. J Pharmacol Exp Ther 1987;240:51-8.

35 Casale TB, Ecklund P. Characterization of muscariniç receptor subtypes in human peripheral lung. $J$ App Physiol 1988;65:594-600.

36 Mak JCW, Barnes PJ. Muscarinic receptor subtypes iñ guinea pig and human lung. Eur J Pharmacol (in press).

37 Mak JCW, Barnes PJ. Autoradiographic visualization of muscarinic receptor subtypes in human and guinea pig3 lung. Am Rev Respir Dis (in press).

38 Kilbinger $\mathrm{H}$, Wessler I. Inhibition of acetylcholine of the stimulation-evoked release of $\left[{ }^{3} \mathrm{H}\right]$ acetylcholine from the guinea-pig mycenteric plexus. Neurosci Lett 1980 . 5:1331-40.

39 Fryer AD, Maclagan J. Muscarinic inhibitory receptors in pulmonary parasympathetic nerves in the guinea-3 pig. Br J Pharmacol 1984;83:973-8.

40 Blaber LC, Fryer AD, Maclagan J. Neuronal muscariniê receptors attenuate vagally-induced contraction oR feline bronchial smooth muscle. Br J Pharmacol 1985 86:723-8.

41 Faulkner D, Fryer AD, Maclagan J. Post-ganglionie muscarinic inhibitory receptors in pulmonar parasympathetic nerves in guinea-pig. $\mathrm{Br} J$ Pharmacoో 1986;88:181-7.

42 Minette PA, Barnes PJ. Prejunctional inhibitory mus carinic receptors on cholinergic nerves in human and guinea-pig airways. J Appl Physiol 1988;64:2532-7.

43 Ito Y, Yoshitomi T. Autoregulation of acetylcholine release from vagus nerve terminals through activatio of muscarinic receptors in the dog trachea. $\mathrm{Br} \mathscr{P}$ Pharmacol 1988;93:636-46.

44 Minette P, Lammers J-W, Barnes PJ. Is there a defect i inhibitory muscarinic receptors in asthma? Am Re Respir Dis 1988;137(suppl):239.

45 Chilvers ER, Barnes PJ, Nahorski SR. Muscarinic recep尺 tor stimulated turnover of polyphosphoinositides an 
inositol polyphosphates in bovine tracheal smooth muscle. Br J Pharmacol 1988;95:778P.

46 Gater P, Alabaster VA, Piper I. Characterisation of the muscarinic receptor subtype mediating mucus secretion in the cat trachea in vitro. Pulm Pharmacol (in press).

47 Connolly CK. Adverse reaction to ipratropium bromide. Br Med J 1982;5:934-5.

48 Fryer AD, Maclagan J. Ipratropium bromide potentiates bronchoconstriction induced by vagal nerve stimulation in the guinea-pig. Eur J Pharmacol 1987;139:
187-91.

49 Shoene RB. Timolol-induced bronchospasm in asthmatic bronchitis. JAMA 1981;245:1460.

50 Ind PW, Dixon CMS, Fuller RW, Barnes PJ. Anticholinergic blockade of beta-blocker induced bronchoconstriction. Am Rev Respir Dis (in press).

51 Barnes PJ. Endogenous catecholamines and asthma. $J$ Allergy Clin Immunol 1986;77:791-5.

52 Rhoden KJ, Meldrum LA, Barnes PJ. Inhibition of cholinergic neurotransmission in human airways by beta $_{2}$-adrenoceptors. J Appl Physiol 1988;65:700-5. 